\title{
THE HISTORY AND SOCIOLOGY OF
}

GENOCIDE 

THE HISTORY AND SOCIOLOGY OF

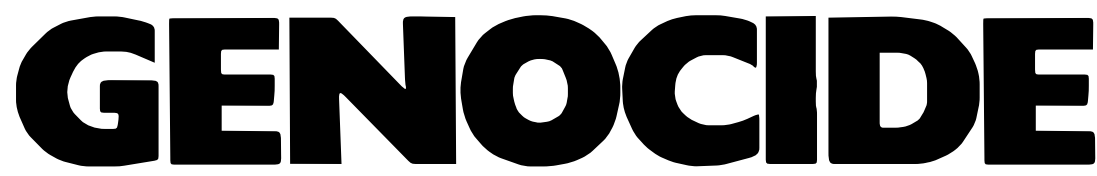

ANALYSES AND CASE STUDIES

FRANK CHALK \& KURT JONASSOHN

PUBLISHED IN COOPERATION WITH THE

MONTREAL INSTITUTE FOR GENOCIDE STUDIES

YALE UNIVERSITY PRESS NEW HAVEN \& LONDON 
Copyright (C) 1990 by Frank Chalk and Kurt Jonassohn. All rights reserved.

This book may not be reproduced, in whole or in part, including illustrations, in any form (beyond that copying permitted by Sections I07 and 108 of the U.S. Copyright Law and except by reviewers for the public press), without written permission from the publishers.

\section{Designed by Richard Hendel}

Set in Times Roman and Gill type by Marathon Typography Service, Inc., Durham, NC

Printed in the United States of America.

\section{Library of Congress Cataloging-in-}

Publication Data

Chalk, Frank Robert, 1937-

The history and sociology of genocide:

analyses and case studies / Frank Chalk and Kurt Jonassohn.

p. $\mathbf{c m}$.

"Published in cooperation with the Montreal Institute for Genocide Studies."

Includes bibliographical references (p. ). ISBN 0-300-04445-3 (alk. paper). ISBN 0-300-04446-I (pbk. : alk. paper)

I. Genocide-History. I. Jonassohn, Kurt. II. Institut montréalais des études sur le genocide. III. Title.

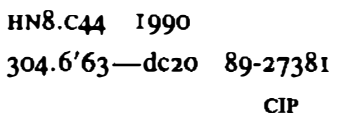

The paper in this book meets the guidelines for permanence and durability of the Committee on Production Guidelines for Book Longevity of the Council on Library Resources.

I0 98 
I N MEMORY OF

Alfred Chalk

(b. Lodz, I90I-d. Miami Beach, I986)

and for

Jennie Klein Chalk

and

Florence and Joseph Hackman

To Shlomo Jannai, who escaped,

and to Richard and Frieda Jonassohn, who did not 

If we could learn to look instead of gawking,

We'd see the horror in the heart of farce,

If only we could act instead of talking,

We wouldn't always end up on our arse.

This was the thing that nearly had us mastered;

Don't yet rejoice in his defeat, you men!

Although the world stood up and stopped the bastard,

The bitch that bore him is in heat again.

-Epilogue to Der Aufhaltsome Aufstieg des Arturo Ui

[The Resistible Rise of Arturo Ui], Bertold Brecht.

Translated by George Tabori. 
